\title{
Take Action: Give A Hope to Minimize Inequality!
}

\author{
Jessica Lee \\ Division of Biology and Chemistry, The BASE, Chapel Hill, NC 27510, USA \\ Correspondence to: Dr. Jessica Lee, Ph.D., E-mail: Jessica.lee@basehq.org \\ DOI: https://doi.org/10.15354/si.21.ed006 \\ The author declares no competing interest.
}

\begin{abstract}
From equality to inequality, the equilibrium point fluctuates all the time. How to balance and minimize the negative impact of inequality on the individual's socioeconomic, educational, psychological, and overall health is critical. Even it is of extremely difficult to realize the real equality, it is still worthwhile to take action to minimize the inequality.
\end{abstract}

Keywords: Inequality; Intergenerational Transmission; Economy; Education; Health; Psychology

Science Insights, 2021 December 28; Vol. 39, No. 5, pp.375-376.

(C) 2021 Insights Publisher. All rights reserved.

(c) (1) (8) Creative Commons Non Commercial CC BY-NC: This article is distributed under the terms of the Creative Commons Attribupermission provided the original work is attributed by the Insights Publisher.

"It is a wise man who said that there is no greater inequality than the equal treatment of unequals."

- Felix Frankfurter

$\mathrm{E}$ QUALITY is a long-standing but new topic. Pursuing equality is a vital social need $(1,2)$. However, equality is a relative concept; there is no absolute equality. No matter what matters, including economy, education, and health, they were not equal at the beginning. Most of the time, we cannot avoid the potential impact of inequality. Of course, how to face and minimize inequality in the reality where inequality is everywhere is the ability that each of us needs to possess.

Economic inequality is often the focus of attention (3). The world's economic differences between countries and regions are apparent. All other secondary inequalities caused by economic inequality should be paid more attention to. Educational inequality, which is directly related to the economy, is a thorny issue that all countries face and need to solve (4). However, this road is complex and long. The health differences that follow economic development inequality should not be ignored. The overall health of residents in an area is closely related to the local economy (5). However, the individual's health is also one of the essential contributors to inequality $(6,7)$. Regardless of the economy, education, or health inequality, they will all have a different psychological impact on individuals. Furthermore, this negative impact on mental health will further hinder the improvement of the individual's economic status, affect them receiving a good education, and ultimately affect overall health.

Being able to face all kinds of inequality is already a big step forward. Analyzing various inequalities and drawing appropriate constructive opinions will have fundamental practical and social significance. Therefore, in this issue of Science Insights, authors analyzed the inequality from different aspects, including economy, education, health, and psychology at different levels (8-11). It is hoped that all aspects of inequality can be paid attention to by all parties. The in-depth understanding of various inequalities can provide an essential reference for policymakers. Although its role in promoting equality cannot be accurately estimated, we choose the former between "Action" and "No Action". Because as long as there is action, there is hope! 


\section{References}

1. Spicker P. Why freedom implies equality. J Appl Philos 1985; 2(2):205-216. Available at: http://www.jstor.org/stable/24353449

2. Queiroz R. Individual liberty and the importance of the concept of the people. Palgrave Commun 2018; 4:99. DOI: https://doi.org/10.1057/s41599-018-0151-3

3. Knell M, Stix H. Inequality, perception biases and trust. J Econ Inequal 2021; 19:801-824. DOI: https://doi.org/10.1007/s10888-021-09490-x

4. Pfeffer FT. Growing wealth gaps in education. Demography 2018; 55(3):1033-1068. DOI: https://doi.org/10.1007/s13524-018-0666-7

5. Institute of Medicine (US) Committee on Assuring the Health of the Public in the 21st Century. The Future of the Public's Health in the 21st Century. Washington (DC): National Academies Press (US); 2002. 2, Understanding Population Health and Its Determinants. Available at: https://www.ncbi.nlm.nih.gov/books/NBK221225/

6. National Academies of Sciences, Engineering, and Medicine; Health and Medicine Division; Board on Population Health and Public Health Practice; Committee on Community-Based Solutions to Promote
Health Equity in the United States; Baciu A, Negussie Y, Geller A, et al., editors. Communities in Action: Pathways to Health Equity. Washington (DC): National Academies Press (US); 2017 Jan 11. 3, The Root Causes of Health Inequity. Available from: https://www.ncbi.nlm.nih.gov/books/NBK425845/

7. McCartney G, Popham F, McMaster R, Cumbers A. Defining health and health inequalities. Public Health 2019; 172:22-30. DOI: https://doi.org/10.1016/j.puhe.2019.03.023

8. Sharma S, Prakash A. Intergenerational transmission of inequality in psychological health. Sci Insig 2021; 39(5):379-390. DOI: https://doi.org/10.15354/si.21.re251

9. Lyu K, Niu X, Zhou Y. An economic perspective on the intergenerational transmission of wealth inequality Sci Insig 2021; 39(5):391-400. DOI: https://doi.org/10.15354/si.21.re257

10. Wang C. The Effects of Intergenerational Transmission on Education. Sci Insig 2021; 39(5):401-406. DOI: https://doi.org/10.15354/si.21.re260

11. Will $D$, Wang F. On the intergenerational transmission of health inequality. Sci Insig 2021; 39(5):407-418. DOI: https://doi.org/10.15354/si.21.re262 